doi:10.18575/msrs.sm.s.16.12 UDK: 616-006

COBISS.RS-ID: 5700376

\section{Značaj humanih papiloma virusa u nastanku karcinoma glave i vrata}

\section{SAŽETAK}

Karcinomi glave i vrata su heterogena grupa oboljenja. Histopatološki, to su planocelularni karcinomi pločasto slojevitog epitela (engl. HNSCC) kože glave i vrata, sluznica gornjeg aerodigestivnog trakta, farinksa i larinksa. HNSCC je peti najčešći maligni tumor kod ljudi širom svijeta. U najvećem broju slučajeva HNSCC se dovodi u vezu sa konzumacijom alkohola i duvana. Poslednjih godina rađena su istraživanja čiji je cilj bio dokazati ulogu humanih papiloma virusa (HPV) u karcinogenezi HNSCC. Prevalenca HPV-a u HNSCC je oko 30\%. HPV je češće detektovan u biološkom materijalu osoba muškog pola. Osobe sa HPV pozitivnim HNSCC bolje reaguju na terapiju i imaju povoljniji ishod liječenja u odnosu na pacijente kod kojih nije dokazan HPV. U budućnosti, HPV treba da bude marker koji će uticati na izbor terapije kod oboljelih od HNSCC, ali i faktor koji će ukazati na ishod ovog malignoma kod pacijenata.

KIjučne riječi: HPV, karcinom glave i vrata, dijagnostika

(Scr Med 2016:47:69-73)
Ljiljana Božić,"

Smija Jovičić, Aleksmdra Śmitrant

${ }^{1}$ Katedra za mikrobiologiju i imunologiju Medicinskog fakulteta u Banjaluci

${ }^{2}$ Katedra za histologiju i embriologiju Medicinskog fakulteta u Banjaluci

\section{Kontakt adresa:}

Ljiljana Božić

Katedra za mikrobiologiju

i imunologiju

Medicinski fakultet u Banjaluci

e-mail: ljlj.ljilja@gmail.com

tel: o03876590967o

Rad primljen:29.1.2016.

Rad prihvaćen:10.2.2016

\section{Uvod}

Prema modifikovanoj Borstovoj (Borst) definiciji „Tumor je lokalno, atipično, autonomno, nергеstano i nesvrsishodno bujanje tkiva". Karcinomi glave i vrata (engl. Head and Neck squamous cell caricinoma -HNSCC) su heterogena grupa oboljenja. Histopatoloski, to su planocelularni karcinomi pločasto slojevitog epitela kože glave i vrata, sluznica gornjeg aerodigestivnog trakta, farinksa i larinksa. ${ }^{2}$ HNSCC je peti najčešći maligni tumor kod ljudi širom svijeta. ${ }^{3}$ Procijenjeno je da se godišnje pojavi 560,000 novih slučajeva, sa smrtnim ishodom kod oko 301,000 pacijenata. ${ }^{4}$ Poslednjih godina raste incidenca ovog karcinoma u zemljama u razwoju. ${ }^{5}$ U Sjedinjenim Američkim Državama (SAD) uočen je porast incidence HNSCC kod osoba mlađe dobi, muškaraca, te pripadnika bijele rase. ${ }^{{ }^{6} 7}$ Prema SEER Database (Cancer statistics rewiew 1975-2010), ${ }^{B}$ stopa oboljevanja kod muškaraca i žena crne $\mathrm{i}$ bijele rase 2010. godine bila je 10,79:100,000 stanovnika, a stopa mortaliteta kod oba pola bila je 2,47:100,000. HNSCC se češće javlja kod muškaraca starije žvotne dobi (>65 godina života), a utvrđeno je da HNSCC i kod muškaraca $\mathrm{i}$ kod žena najčešce zahvata farinks, ${ }^{9}$ jezik i tonzile. ${ }^{5}$ 


\section{Humani papiloma virusi i HNSCC}

Više faktora je ukjučeno u etiopatogenezu karcinoma glave i vrata. U $75 \%$ slučajeva karcinon glave i vrata sedovodi u vezu sa konzumacijom alkohola i duvana (preko 20 cigareta dnevno). ${ }^{7}$ Prethodnih godina rađene su studije koje ukazuju na to da humani papiloma virus (HPV) učestvuje u patogenezi HNSCC. ${ }^{8}$

HPV je DNK virus (porodica Papillomaviridae) sa kapsidom i kozaedarne simetrije koji grade dva struktruna proteina koja formiraju 72 kapsomere. Genom je građen iz dvolančane cirkularne DNK dužine 8ooobp. Dijeli se na nekoliko regiona: $\mathrm{E}$ region (od engl. early) sadři gene za E6 i E7 onkoproteine, E2 koji predstavlja transkripcijski faktor, kao i gene E4 za helikazu, E5, E1 i E2; L region (od engl. late) koji kodira za strukturne proteine kapsida L1 i L2, kao i LCR (od engl. long control region), nekodirajući region koji je odgovoran za virusnu repilkaciju i ekspresiju gena (Slika 1.).

Slika 1. Građa genoma HPV-a (preuzeto iz Hadžisejdić, Ita, Magdalena Grce, and Blaženka Grahovac. "Humani papiloma virus i karcinom cerviksa: mehanizmi karcinogeneze, epidemiologija, dijagnostika i profilaksa." Medicina Fluminensis 46.2 (2010): 112-123.

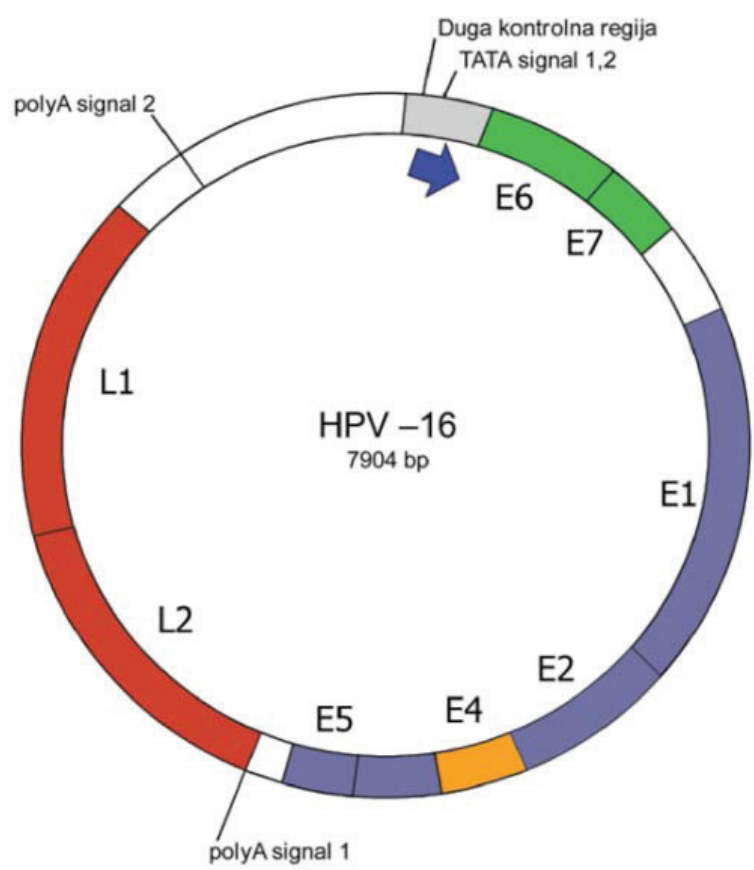

Postoji vise od 150 tipova HPV-a, a u odnosu na onkogeni potencijal mogu biti niskoonkogeni i visokoonkogeni. Od visokonkogenih tipova HPV-a пајzпас̌ајпіji su: 16, 18, 31, $33,35,39,45,51,52,56,58,59,66$ i 68 , a od niskoon- kogenih: $6,11,40,42,43$ i 44. Ovo je epiteliotropni virıs,uzrokuje hiperplastične, papilonatozne $\mathbf{i}$ bradavičaste promjene na pločastoslojeviton epitelu kože i shuznica. ${ }^{9}$ Može biti prisutan i na zdravoj shznici. HPV je glavni etiološki faktor karcinoma grlića materice, ${ }^{5}$ te se zbog histološke sličnosti sluznice anogenitalnog trakta i orofarinksa temelji na povezanosti HPV i HNSCC.

Kod infekcija visokoonkogenim tipovima, onkoproteini E6 i E7 inhibiraju tumor supresorske gene- $\mathrm{Rb}$ (retinoblastom)i p53 i tako indukuju genetsku nestabilnost na паčin da interferiraju sa kontrolnim tačkama ćelijskog ciklusa, te na taj način sprečavaju apoptozu, uzrokujući dalje nakupljanje mutacija i izostanak reparacije DNK. Niskoonkogeni tipovi HPV-a pokazuju slab afinitet za domaćinske supresorske gene, pa su takve infekcije samoograničavajuće i prolaze bez posljedica. ${ }^{4}$

Prevalenca HPV-a u HNSCC je oko 30\%. Razlog tome treba tražiti u etničko-geografskim razlikama, veličini uzorka, načinu ishrane, seksualnim navikama i metodama detekcije HPV-a u biološkom materijalu pacijenta. Varijabilnost u detekciji HPV-a često je posljedica različitih metoda ali i načina uzimanja uzorka (bris, ispirak, sviježe tkivo, tkivo uklopljeno u parafin). ${ }^{4}$

Gillison i saradnici ${ }^{1 \circ}$ Su utvrdili HPV kod $25 \%$ HNSCC, a najčešći tip je bio tip 16. Pacijenti sa HPV pozitivnim karcinomon su inali bolju prognozu. Utvrđeno je da postoji razlika i klinički i patohistoloski HPV pozitivnih i HPV negativnih karcinoma. Kod pacijenata kod kojih je detektovan HPV, maligne promjene su manjih dimenzija,histološki nekeratinizirane, rijetko dolazi do šrenja malignih ćelija u limfne čvorove, a odlikuje ih slaba diferencijacija. ${ }^{10}$

Karcinom usne duplje i orofarinksa predstavlja šesti najčešći karcinom u svijetu, sa najvećom incidencom u Indiji i Juogoistočnoj Aziji, zbog navika stanovnišsva (Žvakanje betelowog oraščića). ${ }^{11}$ 2008. godine zabilježeno je 400,000 oboljelih od karcinoma orofacijalne regije, sa smrtnim ishodom kod 223,000 pacijenata. ${ }^{11}$ Rezultati studije koja je obuhvatila 23 zemlje ukazuju da je najveća incidenca orofaringealnog karcinoma bila među muškarcima u Francuskoj, Slovačkoj i Velikoj Britaniji. ${ }^{10}$ Učestalost HPV pozitivnih orofaringealnih karcinoma posljednjih godina je povećana, što se ne može potvrditi i za malignome drugih drugih regija glave i vrata. ${ }^{12}$ Rezultati studije sprovedene u SAD-u su pokazali da tip HPV 16 najčešce uzrokuje oralne infekcije. ${ }^{12}$ Čnjenica je da se broj HPV pozitiwnih orofaringealnih karcinoma povećao kod pacije nata koji u anamnezi negiraju konzumaciju duvana i alkohola. ${ }^{7}$ 
Kreimer i saradnici ${ }^{13}$ gu u sistematskom pregledu literature objavili učestalost HPV u HNSCC i to 23,5\% kod karcinoma usne duplje, 24\% kod karcinoma larinksa, pri čemu je prevalenca karcinoma slična kod oba pola. Od strane Sirjanena i saradnika ${ }^{14}$ utvrđeno je da je HPV učestaliji u prekanceroznim lezijama (leukoplakija,lihen, i dr.).

Obrađujući uzorke pacijenata iz Indije, Murray i kolegeg su dokazali HPV kod $25 \%$ oboljelih od karcinoma orofaringealne regije, dok je studija u Aziji pokazala da je učestalost karcinoma usne šupljine bila od 66\% do $100 \%$, što može uputiti da HPV u kombinaciji sa dijetetskim navikama i genetskom predispozicijon dowodi do nastanka ovog malignoma.9 Rezultati ovih studija odstupaju od podataka dobijenih istražvanjem u Južnoafričkoj Republici, gdje je učestalost HPV pozitivnih karcinoma usne šupljine iznosila od $0 \%$ do $11,9 \%{ }^{12}$

Termine $\mathbf{i}$ saradnicis su u meta analizi objavili da je prevalenca HPV-a u karcinomu usne šupljine $38,1 \%$. Ovo je rezul tat analize 47 studija, odnosno analize uzoraka 3583 bolesnika šrom swijeta.

Poslednjih godina raste broj karcinoma baze jezika i tonzila, i u više od $70 \%$ slučajeva je češći kod muškaraca. Takođe je uočen pad tendencije pušenja kod ovih pacijenata. ${ }^{3}$ Kreimer i saradnici ${ }^{13}$ su objavili da je prevalenca HPV-a u orofaringealnom karcinomu u Sjevernoj Americi $47 \%$, u Aziji 46\% i u Evropi 28\%. Ta različitost može da se dovede u vezu sa načinom uzorkovanja bolesničkog materijala, metodom dokazivanja HPV-a u biološkon materijalu, ali zavisi i od anatonske lokalizacije samog uzorka. Dokazano je da je HPV značajno više detektovan u svježem tkivı. ${ }^{4}$ DNK se u tkivı ukalupljenom u parafinvremenom fragmentuje, i kao takvu ju je teže dokazati. S toga je preporuka da se koriste tkiva ukalupljena u parafin stara do pet godina. Takođe je bitno da se zna iz kog anatomskog dijela uzorci tkiva potičı, kako bi se izbjegla greška u analizi stope prevalence HPV-a u tumorima glave i vrata. U Sloveniji je rađena studija na uzorku od 62 pacijenta u kojoj je dokazano prisustvo HPV-a u $8,4 \%$ slučajeva, a detekcija je vršena PCR (Polymerase chain reaction, engl.) metodom iz parafinskih blokova. ${ }^{16}$ PCR metodom se ne može utvrditi da li je HPV integrisana u humani genom ili je u epizomalnoj formi, s toga bi trebalo da se radi RT-PCR (od engl. Reverse transcription. polymerase chain reaction) koji ukazuje na aktivnost virusa, te bi se se na taj način potvrdila njegova powezanost sa malignom alteracijom ćelija. ${ }^{4}$ Ovo predstavlja tehniči dugotrajan i zahtijevan metod. S toga se HPV češce dokazuje klasičnim i PCR metodama u dva kruga (engl. ne- sted PCR). To je često razlog lažno pozitivnih rezultata, a postoji i opasnost da dođe do kontaminacije HPV-om iz okolnog zdravog tkiva. U zdravoj sluznici usne duplje otkriveni su sljedeći tipovi HPV-a: 2, 6, 7, 11, 13, 16, 18, 31, 33 i 35. Značaj prisustva HPV-a u zdravoj sluznici jos̆ nije poznat. U benignim i malignim lezijama glave i vrata detektovana su 24 različita tipa HPV-a:1, 2, 3, 4, 5, 6, 7, $10,11,13,16,18,31,32,33,35,39,45,51,52,55,56,57$, $58,59,66,69,72$ i 73.16

Već je napomenuto da incidenca karcinoma usne duplje i orofarinksa raste poslednjih 20 godina, a trend pušenja opada. Upravo su zbog toga i rađene studije koje imaju za cilj da potvrde povezanost duvana i HPV sa HNSCC. Uočena je povećana učestalost karcinoma usne duplje $\mathbf{i}$ to najčešce kod muškaraca mlađih od 60 godina, koji ne spadaju u grupu rizičnih pacijenata, ${ }^{7}$ što može da se poveže sa promjenom seksualnih navika.

HPV u karcinomu glave i vrata predstavlja važan prognostički marker i ukazuje na ishod liječenja. Bez obzira na interdisciplinaran pristup u liječenju, mortalitet owe bolesti se nije promijenio zadnjih 40 godina. Prema nekim studijama, petogodišnje preživjavanje varira od $40 \%$ do 50\%.3 Zbog toga HPV u budućnosti može biti faktor koji će uticati na izbor terapije. Pojavio se inovi RNK-scope test, HPV test tehnika in situ hibridizacije kojon se detektuje E6/E7 mRNK (od engl. messenger RNA) do 18 visokoonkogenih tipova. Ovaj test se ne primjenjuje klinički. Pokazano je da postoji povezanost ekspresije p16 i HPV pozitivnog orofaringealnog karcinoma. Međutim, po nekim autorima p16 nije pouzdan da bude specifičan za onkogenezu izazvanu HPV-om.

\section{Zaključak}

Prema današnjim saznanjima, HPV je najvažniji etiološki uzročnik karcinoma grlića materice, što jos̆ nije dokazano za HNSCC. Bez obzira na ovı činjenicu, HPV u budućnosti svakako treba da bude marker koji ce uticati na izbor terapije kod oboljelih od HNSCC, ali i faktor koji će ukazati na ishod ovog malignoma u humanoj populaciji.

\section{Reference}

1. Gavrić M. Maksilofacijalna hirurgija. Beograd: Draganić, 2001 .

2. Marur, Shanthi, et al. "HPV-associated head and neck cancer: a virus-related cancer epidemic." The lancet oncology $11 .^{8}$ (2010): 781-789.

http//dx.doi.org/10.1016/S1470-2045/10)70017-6 
3. Termine N, Panzarella V, Falaschini S, Russo A, Matranga D, Lo Muzio L, Campisi G. HPV in oral squamous cell carcinoma vs head and neck squamous cell carcinoma biopsies: a meta-analysis (1988-2007). Ann Oncol. 2008 Oct;19(10):168190.

http://dx.doi.org/10.1093/annone/mdn372 PMid: 18558666

4. Cartwight, S.J. (2014) A Review of Literature Pertaining to Head and Neck Squamous Cell Carcinoma with Emphasis on the Role of the Human Papilloma Virus. International Journal of Otolarygology and Head and Neck surgery, 3, 279-292.

5. Elwood JM, Youlden DR, Chelimo C, Ioamides SJ, Baade PD. Comparison of oropharyngeal and oral cavity squamous cell cancer incidence and trends in New Zealand and Queensland, Australia. Cancer Epidemiol. $2014 \mathrm{Feb} ; 38\{1\} \div 16-21$. http://dx.doi.org/10.1016/j.canep.2013.12.004 PWid:24445141

6. Chaturvedi AK, Engels EA, Pfeiffer RM, Hernandez BY, Xiao W, Kim E, Jiang B, Goodman MT, Sibug-Saber M, Cozen W, Liu L, Lynch CF, Wentzensen N, Jordan RC, Altekruse S, Anderson WF, Rosenberg PS, Gillison ML. Human papillomavirus and rising oropharyngeal cancer incidence in the United States. J Clin Oneol. 2011 Nov $10,29(32): 4294-301$.

http://dx.doi.org/10.1200/JC0.2011.36.4596 PMid:21969503 PMCid:PMC3221528

7. Benson E, Li R, Eisele D, Fakhry C. The clinical impact of HPV tumor status upon head and neck squamous cell carcinomas. Oral Oneol. 2014 Jum;50(6):565-74.

http//dx.doi.org/10.1016/j.oraloneology.2013.09.008 PMid:24134947 PMCid:PMC4391706

8. Venuti A, Paolini F. HPV detection methods in head and neck cancer. Head Neck Pathol. 2o12 Jul;6 Suppl 1:S63-74.

http://dx.doi.org/10.1007/s12105-012-0372-5 PMid:22782225 PMCid:PMC3394157

9. Murray PR, Rosenthal KS, Kobayashi GS, Pfaller MA. Medical microbiology. 7th ed. St. Louis: Mosby; 2002.
10. Gillison ML, Koch WM, Capone RB, Spafford M, Westra WH, Wu L, et al. Evidence for a causal association between human papillomavirus and a subset of head and neck cancer. J. Natl Cancer Inst $2000 \div 92 \div 709-20$. http://dx.doi.org/10.1093/jnei/92.9.709

11. Chocolatewala NM, Chaturvedi P. Role of human papilloma virus in the oral carcinogenesis: an Indian perspective. J Cancer Res Ther $200955: 71-7$.

http://dx.doi.org/10.4103/0973-1482.52788

PMid:19542661

12. Ferlay J, Shin HR, Bray F, et al: Estimates of worldwide burden of caneer in 2008: GLOBOCAN 2008. Int J Cancer $127 \div 2893-2917,2010$.

http//dx.doi.org/10.1002/1je.25.516

PMid 21351269

13. Kreimer AR, Clifford GM, Boyle P, Franceschi S. Human papillomavirus types in head and neck cell carcinomas worldwide: a systematic review. Cancer Epidemiol Biomarkers Prev. 2005; $14\{2\}: 467-75$.

http://dx.doi.org/10.1158/1055-9965.EPI-04-0551 PMid:15734974

14. Syrjamen S, Lodi G, von Bultzingslowen I, Aliko A, Arduino P, Campisi $G$ et al. Human papillomaviruses in oral carcinoma and oral potentially malignant disorders: a systematic review. Oral Dis. 2011;17 Suppl $1: 58-72$.

http://dx.doi.org/10.1111/j.1601-0825.2011.01792.x PMid:21382139

15. Ramqvist $T$, Grün N, Dalianis $T$. Human papillomavirus and tonsillar and base of tongue cancer. Viruses. 2015 Mar $20 ; 73) \div 1332-43$

ht t p://dx.doi.org/10.3390/y 7031332 PMid:25803099 PMCid:PMC4379573

16. Kansky AA, Poljak M, Seme K i sur. Human papillomavirus DNA in oral squamous cell carcinomas and normal oral mucosa. Acta Virol $200344: 11-6$. PMid:12828338 


\title{
The Significance of Human Papillomaviruses in Head and Neck Cancer Development
}

\begin{abstract}
Head and neck cancers (HNC) are a heterogeneous group of diseases. Histopathological, these are head and neck squamous cell carcinoma (HNSCC) epithelium of the skin, mucosa of the upper aerodigestive tract, pharynx and larynx. HNSCC is the fifth leading cause of cancer worldwide. The most important risk factors are alcohol and smoking. In the recent years, the studies have been conducted in order to prove the role of HPV in HNSCC carcinogenesis. The prevalence of HPV in HNSCC is 30\%. HPV is often detected in biological materials of males. People with HPV positive HNSCC respond better to treatment and have a better treatment outcome than patients with no proven HPV. In the future, HPV should be the marker that will influence the choice of therapy in patients with HNSCC, but also the factor that will indicate the outcome of this malignancy in the human population.
\end{abstract}

Key words: HPV, head and neck cancer, diagnosis 